\title{
STANY EMOCJONALNO-SPOLECZNE WŚRÓD MŁODZIEŻY AKADEMICKIEJ W OKRESIE PANDEMII COVID-19 (RAPORT Z BADAŃ)
}

\section{Wprowadzenie}

Okres pandemii spowodowanej wirusem SARS-CoV-2 wpłynął zasadniczo na zmiany stanów emocjonalno-społecznych Polaków i wymusił adaptację do nowych warunków. Poczynając od marca 2020 r., kiedy odnotowano pierwsze przypadki zachorowań, sytuacja pandemiczna w kraju zmieniała się niemal z dnia na dzień. Z „lokalnej” choroby epidemia przekształciła się w szybko rozwijającą się, budzącą strach globalną pandemię (WHO, 2020). Zmiany, jakie nastąpiły w wyniku pandemii, dotknęły wszystkich obszarów życia: rodziny, pracy, relacji z bliskimi osobami oraz stopniowo ograniczyły zwykłą aktywność, nie pozwalając o zadbanie o siebie w dawny, naturalny dla nas sposób (Ćosić i in., 2020, s. 25-31). Zmiany te były i są przedmiotem licznych badań, prowadzonych przez różne instytucje, jak i osoby indywidualne (Chodkiewicz i in., 2020; Gawrych, 2020; WHO, 2020). $\mathrm{Z}$ reguły ich celem jest określenie, jak wprowadzony okres kwarantanny wpłynął na zachowania ludzi i jakie będą tego ewentualne konsekwencje na przyszłość. Epidemia dotknęła wszystkich warstw społecznych, w tym także dzieci i młodzież, nie wyłączając młodzieży akademickiej. Określenie tych zmian było celem badań, jakie przeprowadzono wśród studiujących na początku $2021 \mathrm{r}$.

\section{Metodologia i organizacja badań}

Badania prowadzono metodą sondażu diagnostycznego, wykorzystując jako narzędzie autorski kwestionariusz ankiety. W przygotowaniu kwestionariusza bazowa- 
no na opracowaniu J. Heitzmana, który wyróżnił podstawowe kategorie objawów w pandemicznym zaburzeniu stresowym, a zaliczył do nich:

- objawy natręctwa (nieustanne powracanie do istniejącego zagrożenia w rozmowach, natarczywe śledzenie informacji w mediach związanych z COVID-19, sny związane z pandemią, poczucie nierzeczywistego zagrożenia, poczucie krzywdy, nadmierna dbałość o higienę);

- zaburzenia nastroju (wahadło nastrojów od smutku do radości, poczucie zagrożenia wirusowego u osób z grupy ryzyka, nawroty myśli samobójczych w związku z utrudnieniami w leczeniu dotychczasowych schorzeń, wybuchy gniewu, stany depresyjne, brak snu lub nadmierna senność, brak zainteresowań, obniżony poziom sprawności intelektualnej);

- objawy dysocjacyjne (brak poczucia własnej tożsamości, oszołomienie i zaburzenia w postrzeganiu, wrażenie wolniej płynącego czasu, nadmierna czujność);

- unikanie (usilne unikanie traumatycznych wspomnień dotyczących sytuacji pandemicznej, unikanie ludzi związanych i kojarzonych z pandemia);

- nadmierna pobudliwość (zaburzenia snu, odczuwanie niekończącego się zmęczenia, brak koncentracji, agresja, nadmierna czujność i nieproporcjonalne reakcje na bodźce zewnętrzne) (Heitzman, 2020, s. 191).

Badania zostały przeprowadzone w pełni anonimowo. Kwestionariusz ankiety zamieszczono w sieci wykorzystując formularz Google. Ankieta była dostępna przez okres dwóch miesięcy; marzec-kwiecień 2021 r. Ankietowani mieli więc za sobą rok przeżyty w warunkach pandemii. W badaniach wzięło udział 76 studentów, w tym 47 kobiet i 29 mężczyzn. W tej grupie byli studenci studiów stacjonarnych i zaocznych, studiujący na kierunkach ścisłych, humanistycznych i pedagogicznych. Uzyskane wyniki zostały poddane analizie statystycznej z wykorzystaniem metod statystyki opisowej i wnioskowania statystycznego.

\section{Wyniki badań}

Od marca 2019 r. pandemia była jednym z głównych tematów poruszanym w mediach publicznych, ale także $\mathrm{w}$ prywatnych rozmowach. Zainteresowanie tym problemem wśród młodzieży akademickiej można określić na średnim poziomie. Większość badanych (59\%) śledziła te informacje sporadycznie, co może świadczyć o obojętności na zachodzące zmiany, natomiast zupełnym lekceważeniem zaistniałej sytuacji i totalnym brakiem zainteresowania pandemią wykazało się 17\% badanach. Systematycznym śledzeniem informacji w mediach zajmowało się $24 \%$ studiujących. Analizując uzyskane wyniki pod względem zamieszkania respondentów okazuje się, że większe zainteresowanie sytuacją pandemiczną w kraju przejawiała 
młodzież mieszkająca na wsi, chociaż wydawać by się mogło, że biorąc pod uwagę kontakty międzyludzkie, wieś była bardziej bezpieczna pod względem ewentualnej infekcji. Uwzględniając płeć badanych osób nie odnotowano w tym przypadku większych różnic. Należy jedynie zwrócić uwagę, że więcej kobiet mieszkających na wsi z zainteresowaniem śledziło informacje o rozwoju pandemii (26\%) niż kobiety $\mathrm{z}$ miast $(23 \%)$.

Do zainteresowania sytuacją pandemiczną nawiązywały także kolejne pytania ankiety, w których badani poproszeni byli o wyrażenie swojego poglądu na faktyczne zagrożenie pandemią. Okazuje się, że wśród młodzieży akademickiej znalazło się 22 koronasceptyków (29\%), traktujących zagrożenie za nierzeczywiste, a informacje zmanipulowane; Pandemia pokazata jak stabym jesteśmy narodem, jak tatwo można manipulować informacjami oraz ludźmi, dopisała jedna z badanych. Pewnym zaskoczeniem może być fakt, że w grupie sceptyków kobiety stanowiły 63\%.

Pomimo różnic w odbiorze informacji o rozwoju pandemii, prawie wszyscy ankietowani z wyjątkiem jednego mężczyzny przyznali, że miała ona zasadniczy wpływ na pogorszenie stanów emocjonalnych. $Z$ pośród kilku możliwych odpowiedzi, najczęściej wybierano zaburzenia snu, przejawiające się trudnościami w zasypianiu oraz ogólnym zmęczeniem. Częściej ta dysfunkcja dotyczyła kobiet (48\%) niż mężczyzn, co może być powiązane z przejawami nadmiernej czujności, która dotknęła 26,3\% pań. Wśród badanych znalazła się także nieliczna grupa osób, uskarżających się na dręczące sny związane z pandemią (2,6\%). Studiujący odczuwali również obniżenie poczucia własnej wartości, dotknęło to w większym stopniu kobiet (38\%) niż mężczyzn (27\%). Połowa osób, które utraciły poczucie własnej wartości, odczuwały równocześnie poczucie krzywdy i cierpienia. Spowolnienie w upływie czasu to równie częste odczucie wśród badanych (28,9\%). Ogólny marazm w jednakowy stopniu dotknął kobiet i mężczyzn, ale zaskakującym może się wydać, że w większym stopniu dotyczyło to mieszkańców miast niż wsi. Spowolnienie to wynikało zapewne z braku kontaktów społecznych i przymusowym odosobnieniem niektórych ankietowanych. Wśród badanych były także osoby, które miały zaburzenia spostrzegania, w tym złudzenia i halucynacje (3,9\%).

Z przeprowadzonych badań wynika, że powszechnym odczuciem, jakie towarzyszyło również badanym w okresie pandemii, było poczucie ogólnego zmęczenia fizycznego i psychicznego. Badanym towarzyszył smutek, zmartwienie i niepokój, brak nadziei na przyszłość i otaczająca pustka. Studiujący odczuwali takie stany emocjonalne, jak frustracja, drażliwość i nawracające wybuchy gniewu, które wpływały ich zdaniem negatywnie na relacje międzyludzkie. Dodatkowo niektórzy ankietowani wymienili także nudę, bierność, większa ochotę na stosunek ptciowy. Te negatywne emocje w jednakowym stopniu dotknęły mężczyzn i kobiet. Zaledwie 9,2\% ankietowanych nie odczuło żadnego z powyższych stanów. 
Bardzo niepokojącym objawem wśród młodzieży akademickiej było załamanie nerwowe, co przejawiało się w kilku przypadkach nawet myślami samobójczymi. Dotyczyło to $4 \%$ kobiet i $10 \%$ mężczyzn. O faktycznym stanie tych osób świadczy fakt, że w pytaniu dotyczącym kondycji psychicznej badanych zaznaczali takie odpowiedzi, jak: zaburzenia snu, natrętne śledzenie informacji, utrzymujące się poczucie krzywdy i cierpienia, objawy zaburzonego spostrzegania, poczucie braku własnej wartości, poczucie spowolnienia w upływie czasu, myśli samobójcze.

Pandemia wpłynęła zasadniczo na zmianę dotychczasowego trybu życia, co dotknęło także studiujących, a generalnie wprowadziła pewien nieład. Zaledwie 7,9\% respondentów stwierdziło, że ich dotychczasowe zachowania nie uległy zmianie i w grupie tej znaleźli się wyłącznie mężczyźni. Dezorganizacja dotyczyła różnych aspektów życia. W pierwszej kolejności zaburzeniu uległ rytm codzienny czynności (71,1\%), co szczególnie dotyczyło kobiet (83\%), chociaż odczuła to też większość mężczyzn (62\%). U niektórych osób (9,2\%) pojawiły się nawyki obsesyjnego stosowania zabiegów higienicznych jako środka prewencyjnego. Dbałość o higienę dotyczyła przede wszystkim kobiet.

Poza dezorganizacją codzienności, nastąpiły także zasadnicze zmiany w kontaktach międzyludzkich, wymuszone wprowadzanymi restrykcjami. Jak wynika z przeprowadzonych badań, część młodzieży akademickiej nie stosowała się do wprowadzonych zakazów, a przestrzegało je jedynie 64,5\%. Zdecydowanie bardziej zdyscyplinowane w tym względzie były kobiety (76\%) niż mężczyźni (58\%). Należy też zwrócić uwagę, że ograniczenie kontaktów międzyludzkich było szczególnie uciążliwe dla studiujących w trybie stacjonarnym, zarówno wśród studentek (65\%), jak i studentów (52\%). Pandemia wpłynęła nie tylko na zmianę bieżącego rytmu życia, ale wymusiła także zmianę planów życiowych. Częściej tych zmian dokonywali jednak mężczyźni (58\%), rzadziej kobiety (46\%).

Pomimo trudnych warunków życia codziennego w trakcie pandemii większość badanych $(86 \%)$ nie utraciło zdolności wyrażania pozytywnych uczuć takich jak: zadowolenie, radość, podekscytowanie. W nielicznej grupie 11 osób (14\%) deklarujących całkowitą utratę zdolności do wyrażania pozytywnych uczuć, było 9 kobiet i tylko 3 mężczyzn. Jako uzasadnienie tego stanu ankietowani podawali brak kontaktów międzyludzkich, a co za tym idzie brak ludzi, z którymi można by dzielić tego rodzaju uczucia. Jest mniej okazji do spotkań towarzyskich, dlatego mniej się uzewnętrzniam - to odpowiedź uczestniczki badań. Ogólna apatia, zniechęcenie, ograniczenie wolności, brak radości z życia, stany depresyjne, brak ogólnego zadowolenia to czynniki, na które zwracano także uwagę. Jedna z ankietowanych wskazała na silne oddziatywanie propagandy ze strony telewizji rzadowej, co doprowadza do wzajemnych niesnasek, któtni i zmian światopogladowych $w$ kręu jej najbliższych osób, przez co ograniczona została jej empatia. 
W okresie pandemii zachwianiu uległo poczucie bezpieczeństwa. Przyczyn było kilka. Na pierwszym miejscu ankietowani wymieniali obawy o życie własne oraz najbliższych osób $(63,2 \%)$. W jednakowym stopniu zwracały na to uwagę kobiety i mężczyźni. Znaczny wpływ na ograniczenie poczucia bezpieczeństwa miały także wprowadzone odgórnie ograniczenia i niestabilna sytuacja epidemiologiczna. Odpowiedzi te były zapewne spowodowane bardzo surowymi restrykcjami, jakie wprowadzono w okresie pierwszej fali pandemii, co przy minimalnym, jak podawały media, wskaźniku zachorowań, mogło budzić uzasadnione obawy odnośnie wiarygodności danych i dalszego rozwoju pandemii. Poczucie zagrożenia potęgowała sytuacja w polskich szpitalach i brak logicznego zarządzania, co wpłynęło na ograniczenie ich dotychczasowej działalności. Na zły stan ogólnomedyczny spowodowany brakiem możliwości leczenia dotychczasowych schorzeń, zwróciło uwagę $21,27 \%$ badanych. Zaskakujące może się wydać, że stosunkowo niewielki procent badanych $(19,25 \%)$ odczuwał zagrożenie infekcją wirusową. Obawy te wyrażały przede wszystkim kobiety, gdyż zaledwie 4 mężczyzn zaznaczyło taką odpowiedź. Jednym z aspektów osłabienia bezpieczeństwa była obawa utraty płynności finansowej i tym samym środków do życia (19,25\%). W tym przypadku większe obawy wykazywali mężczyźni (27\%) niż kobiety (23\%). Co ciekawe, wśród mężczyzn wszystkie odpowiedzi pochodziły od studentów studiów stacjonarnych, wśród pań była względna równowaga.

Ograniczenie kontaktów międzyludzkich, wprowadzenie zdalnej nauki i zdalnego systemu pracy z pewnością mogły wpłynąć na spadek kondycji fizycznej społeczeństwa. Potwierdzają to także przeprowadzone badania, z których wynika, że tylko 16\% badanych nie odczuło spadku formy czy pogorszenia zdrowia fizycznego, a 31\% utrzymało swoją kondycję na tym samym poziomie. Gorzej pod względem fizycznym czuły się kobiety, z których tylko $8 \%$ zachowało dawną sprawność fizyczną. Wraz ze spadkiem aktywności ruchowej pojawiło się osłabienie i spadek energii u większości badanych (64,5\%), zmęczenie i spowolnienie ruchowej $(27,6 \%)$. Rozkład odpowiedzi w grupach pod względem płci był niemal taki sam, z wyjątkiem odczuwania zmęczenia, na które częściej uskarżały się kobiety (57\% - kobiety; 41\% - mężczyźni). Natomiast spadek aktywności ruchowej był zjawiskiem powszechnym, gdyż zaledwie dwie osoby badane stwierdziły, że tak aktywność u nich wzrosła.

Badania miały także potwierdzić, czy sytuacja pandemiczna wpłynęła na zmianę motywacji do nauki. Z przeprowadzonych badań wynika, że ogólny spadek motywacji odnotowano u $64,5 \%$ badanych. Zjawisko to w większym stopniu dotyczyło mężczyzn, wśród których $44 \%$ straciło całkowicie chęć do nauki, podczas gdy wśród kobiet wskaźnik ten wyniósł 26\%. Porównując w tym przypadku studentów studiów stacjonarnych ze studentami zaocznymi, korzystniej wypada- 
ła pierwsza grupa badanych. Podczas gdy 32\% studentek studiów stacjonarnych utrzymało motywacje na dotychczasowym poziomie, to na studiach zaocznych już tylko 23\%. Natomiast mężczyźni okazali się w tym względzie bardziej odporni, bo $41 \%$ studentów zaocznych nie zmieniło swojego podejścia do nauki, z czego $61 \%$ to studenci studiów stacjonarnych. Badając przejawy spadku motywacji do nauki, w jednym z pytań zaproponowano ankietowanym trzy możliwe odpowiedzi: utrata zainteresowań, obniżenie poziomu koncentracji, trudności z zapamiętywaniem i ostatnia odpowiedź, w której można było wskazać żadne z powyższych. Z tej ostatniej możliwości skorzystało $27,6 \%$ ankietowanych. Najczęstszym przejawem spadku motywacji do nauki było obniżenie poziomu myślenia i utrata koncentracji, która wystąpiły u $67,1 \%$ badanych, w tym u $70 \%$ kobiet i u $65 \%$ mężczyzn. Nie są to jednak wielkie różnice, podobnie jak w przypadku utraty zainteresowań, które zdeklarowało $37 \%$ mężczyzn i 42\% kobiet. Natomiast w znacznie mniejszym stopniu ankietowani odczuwali problemy z pamięcią (32,6\%). Na tę dolegliwość uskarżały się zdecydowanie kobiety (42\%).

Z efektywnością studiów wiązało się kolejne pytanie w ankiecie, dotyczące czasu potrzebnego do przygotowania się do zajęć. Uzyskano tu zaskakujące wyniki. Spośród badanych $43 \%$ przyznało, że ten czas uległ wydłużeniu, natomiast mniej więcej tyle samo osób (42\%) stwierdziło, że nie potrzebowało większego nakładu czasu na przygotowanie się do zajęć, a $15 \%$ badanych nawet wymagało tego czasu mniej. Pozostaje to w sprzeczności z poprzednim pytaniem, w którym większość ankietowanych przyznała, że w okresie pandemii pojawiły się trudności w uczeniu się. W tym przypadku można wątpić w wiarygodność uzyskanych odpowiedzi. Wyniki te tym bardziej mogą budzić wątpliwości, ponieważ 75\% badanych stwierdziło negatywny wpływ zaistniałej sytuacji na ich psychikę, co w zdecydowanej większości dotknęło kobiet (80\%) niż mężczyzn (38\%). Trudno przypuszczać, aby pogorszenie stanu psychiki nie miało ujemnych skutków dla procesu uczenia się.

W okresie pandemii nastąpiła wyraźna poprawa w ocenie stosunków międzyludzkich. Nie ulega wątpliwości, że spowodowane to było wprowadzonymi ograniczeniami i kwarantanną, która dotknęła niektóre osoby. Zapewne pod wpływem tych wydarzeń $63,2 \%$ badanych zaczęła przywiązywać większą wagę do bezpośrednich kontaktów. Szczególnie brak kontaktów i możliwości bezpośredniej rozmowy odczuły kobiety (68\%), i to w jednakowym stopniu ze wsi i z miasta. Wśród mężczyzn ta grupa stanowiła 45\%. Osoby, dla których ocena kontaktów międzyludzkich pozostała na tym samym poziomie, to zaledwie $17,1 \%$ badanych i zarówno wśród mężczyzn, jak i kobiet nie przekracza 10\%.

Pomimo obowiązujących ograniczeń, badani mimo wszystko starali się utrzymywać bezpośrednie kontakty w ramach obowiązujących przepisów $(63,2 \%)$. Szczególnie wyróżniali się tu mężczyźni zamieszkujący na wsi (82\%). Wynikało to 
zapewne z faktu, że na wsi nie ma takich możliwości restrykcyjnych jak w mieście i z doświadczenia można stwierdzić, że pomimo zakazów ludność wiejska w znacznie mniejszym stopniu niż miejska ograniczyła bezpośrednie kontakty. Natomiast najpopularniejszą formą rekompensaty niedoborów kontaktów pozostawały portale społecznościowe, z których korzystało 69,7\% badanych. Przy obecnym poziomie rozwoju sieci Internet i powszechnym dostępie do środków komunikacji nie jest to zaskoczeniem. Należy jedynie zwrócić uwagę, że częściej na portalach społecznościowych gościły panie (79\%), nieco mniej z tych kontaktów korzystało panów (55\%). Znacznie mniejszym zainteresowaniem cieszyły się rozmowy telefoniczne $(43,4 \%)$ i podobnie jak w przypadku portali społecznościowych przewaga była tu po stronie kobiet (49\%), zaś liczba mężczyzn, którzy w okresie pandemii częściej sięgali po „komórki”, jest nieco niższa (34\%).

Oprócz rekompensowania bezpośrednich kontaktów, większość ankietowanych starała się poprawiać własne samopoczucie poprzez różne używki, ale trzeba też przyznać, że aż $46,1 \%$ badanych nie zmieniło swojego postępowania w tym względzie, co można uznać za dobry wynik. Odporność taką wykazało $48 \%$ mężczyzn i $47 \%$ badanych kobiet. Uwagę zwraca fakt, że bardziej odporne okazały się kobiety na wsi, z których ponad połowa (56\%) nie zmieniła swojego trybu życia, podczas gdy w mieście było odwrotnie, bardziej stabilni byli mężczyźni, z których 55\% nie uciekało się do żadnych używek. Rozkład odpowiedzi na to pytanie był interesujący. Ankietowani mogli wybierać po kilka odpowiedzi. W sumie w grupie kobiet uzyskano 56 odpowiedzi, w grupie mężczyzn 50. Świadczy to, że mężczyźni nie poprzestawali na jednej używce. $\mathrm{Na} 29$ badanych, 10 zaznaczyło więcej niż jedną odpowiedź, podczas gdy wśród 44 kobiet znalazło się ich zaledwie 7. Dwóch spośród badanych mężczyzn w okresie pandemii uciekało się do alkoholu, tytoniu, narkotyków i środków farmakologicznych. Trzech poprawiało samopoczucie alkoholem, tytoniem i narkotykami. Pozostałych czterech gustowało w alkoholu i tytoniu. Tylko jeden z badanych poza alkoholem i tytoniem wymienił hazard. Wśród kobiet tylko jedna ankietowana wymieniła alkohol, tytoń, narkotyki i środki farmakologiczne. Dwie panie sięgały po alkohol, tytoń i narkotyki, a pozostałe z tej grupy zadawalały się alkoholem i papierosami. Na pierwszym miejscu wśród używek poprawiających samopoczucie znalazł się alkohol, po który sięgało 40,8\% badanych. Ta przypadłość niemal w równym stopniu dotknęła kobiet $(26 \%)$ i mężczyzn (30\%). Na drugim miejscu znalazł się tytoń (25\% badanych). Po papierosa częściej sięgały kobiety (18\%) niż mężczyźni (16\%). Analizując uzyskane dane odnośnie kobiet, okazuje się, że kobiety mieszkające na wsi stanowią zaledwie $20 \%$ palących pań. Podobne proporcje są wśród mężczyzn, gdzie palący ze wsi stanowią $25 \%$ badanych. Na kolejnym miejscu znalazły się środki farmakologiczne, choć nie jest to zbyt liczna grupa $(11,8 \%)$. W tym przypadku zdecydowanie przeważają 
kobiety (12\%), gdy wśród mężczyzn ta grupa stanowi zaledwie 6\%. Książki i filmy nie stanowią w zasadzie odskoczni od problemów i tylko jeden $\mathrm{z}$ ankietowanych mężczyzn zaznaczył taką odpowiedź.

Ankietowani mieli także możliwość wyrażenia własnych odczuć na temat swojej kondycji psychicznej w okresie pandemii, w formie otwartego pytania. $Z$ tej możliwości skorzystało zaledwie dziewięciu badanych, ale nie były to zaskakująco oryginalne odpowiedzi. Zwracano uwagę na takie stany, jak: depresje, fobie społeczne, brak kontaktów i imprez towarzyskich, agresje, egoizm i zatracanie umiejętności kontaktowania się.

\section{Zakończenie}

Przeprowadzone badania wykazały, że okres pandemii wpłynął na ogół negatywnie na środowisko studenckie. Pojawiły się negatywne stany emocjonalne, które osłabiły psychikę badanych, a w niektórych przypadkach doszło nawet do załamania nerwowego i myśli samobójczych. Studiujący utracili poczucie własnej wartości, niektórych dotknęło poczucie krzywdy i cierpienia psychicznego. Pojawiły się obawy o przyszłość i realne zagrożenie o utratę własnego zdrowia i bliskich osób. Ogólne zmęczenie psychiczne i fizyczne, wrażenie spowolnienia upływającego czasu i ograniczenia w kontaktach międzyludzkich wymusiły zmiany w codziennym rytmie dnia, a nawet korekty w planach życiowych. Sytuacja pandemiczna wpłynęła także zasadniczo na osłabienie tempa i motywacji do nauki i pojawienia się takich stanów, jak utrata zainteresowań, obniżenie poziomu koncentracji, trudności z zapamiętywaniem. Niepokojące może się wydać, że już w drugiej fali pandemii wśród młodzieży studiującej było aż 29\% koronasceptyków. Za pozytywne zjawiska można uznać to, że okres izolacji przyczynił się do zwrócenia uwagi na jakość i ilość kontaktów międzyludzkich i właściwe ich docenianie oraz fakt, że skrajnie uciążliwa sytuacja nie spowodowała ucieczki do używek i środków farmakologicznych w celu poprawy samopoczucia.

\section{Bibliografia}

Chodkiewicz J. i in. (2020). Zdrowie psychiczne a epidemia SARS-COV-2 -badania polskie. Dostęp w: https://www.researchgate.net/publication/342845107_Mental_health_and_the_epidemic_SARS-COV-2_-_risk_factors_Polish_research_ Zdrowie_psychiczne_a_epidemia_SARS-COV-2_-badania_polskie [Dostęp: 15.04.2020] 
Ćosić K. i in. (2020). Impact of human disasters and COVID-19 pandemic on mental health: potential of digital psychiatry. „Psychiatr Danub.”, nr 32(1), s. 25-31. Dostęp w: https://pubmed.ncbi.nlm.nih.gov/32303026 [dostęp 04.05.2020]

Gawrych M. (2020). Zdrowie psychiczne w czasie pandemii COVID-19-przeglad literaturym. Dostęp w: https://www.researchgate.net/publication/347963564_ Mental_health_during_COVID-19_pandemic_-a_literature_review_Zdrowie_psychiczne_w_czasie_pandemii_COVID-19_-przeglad_literatury [Dostęp: 20.04.2020]

Heitzman J. (2020). Wptyw pandemii COVID-19 na zdrowie psychiczne. „Psychiatria Polska, nr 54(2).

World Health Organization, 2020. Zdrowie psychiczne i funkcjonowanie psychospoteczne podczas pandemii COVID-19. Dostęp w: https://apps.who.int/iris/ bitstream/handle/10665/331808/WHO-2019-nCoV-MentalHealth-2020.1pol.pdf. [Dostęp: 20.04.2020]

\section{Streszczenie}

Przeprowadzone w 2020 roku badania wykazały, że okres pandemii wpłynął na ogół negatywnie na środowisko studenckie. Pojawiły się negatywne stany emocjonalne, które osłabiły psychikę badanych, a w niektórych przypadkach doszło nawet do załamania nerwowego i myśli samobójczych. Studiujący utracili poczucie własnej wartości, niektórych dotknęło poczucie krzywdy i cierpienia psychicznego. Pojawiły się obawy o przyszłość i realne zagrożenie o utratę własnego zdrowia i bliskich osób. Ogólne zmęczenie psychiczne i fizyczne, wrażenie spowolnienia upływającego czasu i ograniczenia w kontaktach międzyludzkich wymusily zmiany w codziennym rytmie dnia, a nawet korekty w planach życiowych. Sytuacja pandemiczna wpłynęła także zasadniczo na osłabienie tempa i motywacji do nauki i pojawienia się takich stanów, jak utrata zainteresowań, obniżenie poziomu koncentracji, trudności z zapamiętywaniem. Niepokojące może się wydać, że już w drugiej fali pandemii wśród młodzieży studiującej było aż 29\% koronasceptyków. Za pozytywne zjawiska można uznać to, że okres izolacji przyczynił się do zwrócenia uwagi na jakość i ilość kontaktów międzyludzkich i właściwe ich docenianie oraz fakt, że skrajnie uciążliwa sytuacja nie spowodowała ucieczki do używek i środków farmakologicznych w celu poprawy samopoczucia.

Słowa kluczowe: pandemia COVID-19, stany emocjonalne, stany społeczne, młodzież akademicka, zaburzenia pandemiczne, stres, zaburzenia lękowe, stres pourazowy 


\section{The emotional and social state among academic youth during the COVID-19 pandemic (Research report)}

\section{Summary}

The research was conducted in 2020 and showed that the period of the pandemic will generally have a negative impact on the student's community. Among students negative emotional states appeared that weakened the psyche of the respondents, and in some cases there was even a nervous breakdown and suicidal thoughts. The students lost their self-esteem, some were touched by a sense of psychological harm and suffering. Among students there were fears about the future and a real threat to the loss of one's own health and that of relatives. Mental and physical fatigue of students, the impression of slowing down the passage of time and limitations in interpersonal contacts forced changes in the daily rhythm of the day and even corrections in their life plans. The pandemic situation also significantly reduced the pace and motivation to learn and the emergence of such conditions as loss of interests, decreased concentration, difficulty remembering. It may seem disturbing that already in the second wave of the pandemic, as many as $29 \%$ of coronersceptics were among the students who studied there. The positive phenomena were that the period of isolation contributed to drawing attention to the quality and quantity of interpersonal contacts and their proper appreciation, and the fact that the extremely burdensome situation did not result in resorting to stimulants and drugs in order to improve well-being.

Keywords: COVID-19 pandemic, emotional states, social states, academic youth, pandemic disorders, stress, anxiety disorders, post-traumatic stress 